University of Nebraska - Lincoln

DigitalCommons@University of Nebraska - Lincoln

Biological Systems Engineering: Papers and

Publications

Biological Systems Engineering

$1-2011$

\title{
Completely biodegradable soyprotein-jute biocomposites developed using water without any chemicals as plasticizer
}

\author{
Narendra Reddy \\ University of Nebraska-Lincoln, nreddy3@unl.edu \\ Yiqi Yang \\ University of Nebraska-Lincoln, yyang2@unl.edu
}

Follow this and additional works at: https://digitalcommons.unl.edu/biosysengfacpub

Part of the Biological Engineering Commons

Reddy, Narendra and Yang, Yiqi, "Completely biodegradable soyprotein-jute biocomposites developed using water without any chemicals as plasticizer" (2011). Biological Systems Engineering: Papers and Publications. 205.

https://digitalcommons.unl.edu/biosysengfacpub/205

This Article is brought to you for free and open access by the Biological Systems Engineering at DigitalCommons@University of Nebraska - Lincoln. It has been accepted for inclusion in Biological Systems Engineering: Papers and Publications by an authorized administrator of DigitalCommons@University of Nebraska Lincoln. 


\title{
Completely biodegradable soyprotein-jute biocomposites developed using water without any chemicals as plasticizer
}

\author{
Narendra Reddy ${ }^{1}$ and Yiqi Yang ${ }^{1,2,3}$ \\ 1. Department of Textiles, Clothing \& Design, University of Nebraska-Lincoln, Lincoln \\ 2. Department of Biological Systems Engineering, University of Nebraska-Lincoln \\ 3. Nebraska Center for Materials and Nanoscience, University of Nebraska-Lincoln \\ Corresponding author - Y. Yang, Department of Biological Systems Engineering, 234, HECO Building, University of Nebraska-Lincoln, Lincoln, \\ NE 68583-0802, USA; tel 402 472-5197, fax 402 472-0640, email yyang2@unl.edu
}

\begin{abstract}
Soyprotein-jute fiber composites developed using water without any chemicals as the plasticizer show much better flexural and tensile properties than polypropylene-jute composites. Co-products of soybean processing such as soy oil, soyprotein concentrate and soy protein isolates are inexpensive, abundantly available and are renewable resources that have been extensively studied as potential matrix materials to develop biodegradable composites. However, previous attempts on developing soy-based composites have either chemically modified the co-products or used plasticizers such as glycerol. Chemical modifications make the composites expensive and less environmentally friendly and plasticizers decrease the properties of the composites. In this research, soyprotein composites reinforced with jute fibers have been developed using water without any chemicals as plasticizer. The effects of water on the thermal behavior of soyproteins and composite fabrication conditions on the flexural, tensile and acoustic properties of the composites have been studied. Soyprotein composites developed in this research have excellent flexural strength, tensile strength and tensile modulus, much higher than polypropylene (PP)-jute fiber composites. The soyprotein composites have better properties than the PP composites even at high relative humidity (90\%).
\end{abstract}

Keywords: biocomposites, soyprotein, plasticizers, natural fibers

\section{Introduction}

Extensive efforts are being made to develop biodegradable composites using renewable resources in an attempt to replace the non-biodegradable synthetic polymers used for composites (Mohanty et al., 2000; Barkoula et al., 2010). Both matrix and reinforcing materials derived from renewable resources have been used to develop biodegradable composites. Natural biopolymers such as starch and synthetic biopolymers such as poly(lactic acid), polycaprolactone and cellulose acetate are some of the most commonly used matrix materials and jute, kenaf, flax and hemp are some of the most common natural fibers used as reinforcement in biocomposites (Mohanty et al., 2000). Although the use of biopolymers is highly desirable compared to using non-biodegradable polymers, the common natural and synthetic biopolymers have several limitations such as relatively high price limited availability and/or inability to provide composites with desired properties. Chemical modifications to the biopolymers to improve the properties of the composites could make the biopolymers economically uncompetitive to the synthetic polymers and/or reduce the biodegradability of the biopolymers. Therefore, attempts have been made to find alternative sources for biopolymers used in composites.
Lignocellulosic agricultural byproducts such as corn stover, wheat straw, and cotton stalks and agricultural co-products such as soyproteins, wheat gluten and distiller's dried grains are inexpensive, abundantly available and renewable resources that have also been studied for potential use as matrix and/or reinforcing materials in composites (Huda and Yang, 2008a, 2008b, 2009a, 2009b; Zou et al., 2010; Cheesborough et al., 2008). Unlike biopolymers such as PLA that are synthesized from renewable resources, the lignocellulosic agricultural byproducts and co-products are inevitably generated during the processing of grains for food or fuel. Currently, there is very limited use of the agricultural byproducts and coproducts for industrial applications. In our previous researches, we have shown that cornhusks and wheat straw can be used to develop composites suitable for automotive applications (Huda and Yang, 2008a, 2008b, 2009a, 2009b; Zou et al., 2010). Similarly, cornhusks, wheat and soy straw and cotton stalks have been used to obtain natural cellulose fibers for composites and other applications (Reddy and Yang, 2005, 2009a, 2009b).

Considerable efforts have also been made to utilize the coproducts obtained during the processing of corn, wheat and soybeans (Distillers Dried Grains (DDG), wheat gluten and soyproteins, respectively) for composite applications (Chees- 
borough et al., 2008; Song et al., 2008). Composites were prepared by extruding DDGS with polypropylene and phenolic resin (Tatara et al., 2009). Wheat gluten with or without chemical modifications has also been used as a matrix material in composites and to develop thermoplastics. Wheat gluten modified with urea and sodium hydroxide was used as a binder in particle board as a partial substitute to urea formaldehyde resin in particle board (El-Wakil et al., 2007). Wheat gluten was used as matrix and hydroethyl cellulose, hemp and wood fibers were used as reinforcement with glycerol as the plasticizer and compression molded to form thermoplastics (Kunanopparat et al., 2008; Wretfors et al., 2009; Kim, 2008). Recently, methylcellulose microfibers as fillers and wheat gluten plasticized with glycerol as matrix were used to obtain wheat gluten-based green composites (Song and Zheng, 2009).

Similar to DDG and wheat gluten, byproducts of soybean processing (soy oil, soy concentrate and soyprotein isolates) have also been used to develop biocomposites and plastics (Kumar et al., 2002). Epoxide functionalized soybean oils were used as matrix and natural cellulose fibers as reinforcement to develop biocomposites (Tran et al., 2006; Liu et al., 2006). In another report, epoxidized soybean oil was used as a resin and flax fibers were used as reinforcements to develop composites (Liu et al., 2008). Recently, acrylated epoxidized soybean oil was used as a resin with flax and hemp fiber mats as reinforcement and the flexural and tensile properties of the composites were studied (Akesson et al., 2009). Soyprotein concentrate was chemically modified and used as resin with flax fabrics as reinforcement (Chabba and Netravali, 2005a, 2005b; Chabba et al., 2005). Soyprotein was chemically modified using stearic acid to develop resins for plastics and composites (Lodha and Netravali, 2005). The soyprotein resins were blended with ramie fibers as reinforcement to obtain composites. In another report, soyprotein was mixed with starch and glycerol in the presence of sodium sulfite and extruded to form pellets (Otaigbe et al., 1999). In addition to the co-products obtained from processing soybeans, the byproducts obtained from the soybean plants such as soyhulls (Quirino and Larock, 2009) and soybean stems have been used for composites and to obtain natural cellulose fibers (Reddy and Yang, 2009a), respectively.

The above reports show that the co-products of soybean processing can be utilized for composite applications. However, in all of the above reports, the soybean co-products have been chemically modified or plasticized using glycerol or other plasticizers to develop composites and other thermoplastics. Chemical modifications will increase the cost and may also decrease the degradability of the co-products. Composites developed using glycerol as plasticizer had poor properties mainly due to the high moisture sorption by glycerol. For instance, it was shown that the Young's modulus of wheat gluten composites reinforced with hemp fibers decreases from 34.7 to $10.4 \mathrm{MPa}$ when the glycerol content was increased from 20 to $30 \%$ (Kunanopparat et al., 2008). Therefore, it is desirable to use the soybean co-products for composite applications without chemical modifications or plasticizers.

In this research, we have developed biocomposites using soyprotein as the matrix and water as the plasticizer and jute fibers as reinforcement. Water used as plasticizer will evaporate during compression molding and the composites are therefore expected to have better properties than those developed using glycerol or other plasticizers. The effect of composite fabrication conditions on the flexural and tensile properties and the thermal behavior of soyprotein with and without water as plasticizer have been studied. The properties of the soyprotein composites have been compared with similar composites made from polypropylene reinforced with jute fibers.

\section{Materials and methods}

\subsection{Materials}

Commercially available soyprotein (Pro Fam 646) was supplied by Archer Daniels Midlands company (Decatur, IL). Jute fibers were purchased from Bast Fibers LLC (Cresskill, NJ) and had an average denier of 32, tensile strength of $312 \mathrm{MPa}$, breaking elongation of $1.4 \%$ and Young's modulus of 24.3 GPa. Polypropylene fibers were supplied by Drake Extrusion (Martinsville, VA). The PP fibers were of 15 denier and $84 \mathrm{~mm}$ long and crimped. Breaking tenacity of the PP fibers was approximately $300 \mathrm{MPa}$, melting temperature was $162^{\circ} \mathrm{C}$, melt flow index was $20 \mathrm{~g}$ per 10 min measured at $230^{\circ} \mathrm{C}$, crystallinity was $50 \%$, and density was $900 \mathrm{~kg} / \mathrm{m}^{3}$.

\subsection{Composite fabrication}

\subsubsection{Soyprotein-jute composites}

The jute fibers were carded twice on a Louet laboratory scale carding machine to open and parallelize the fibers. The carded fibers in the form of mats were removed from the carding machine and cut to $25.4 \mathrm{~cm} \times 30.5 \mathrm{~cm}$ rectangular pieces. The jute fiber mats were weighed to obtain the required weight of fibers depending on the ratio of the jute fibers and soyprotein used for each composite. The required amount of soyprotein was also weighed and evenly sprayed on the jute fiber mats. Water equivalent to twice the weight of the total jute fibers and soyproteins used was sprayed onto the jute fibers and soyprotein. The weight of the pre-preg before compression was determined to ensure that the same weight was used for each composite. The pre-preg was placed between two aluminum foils and compression molded in a composite press (Carver Inc) at a predetermined temperature and for a particular time at a pressure of $139 \mathrm{MPa}$. Spacers $(3.2 \mathrm{~mm})$ thick were placed at the edges of the composite press to control the density of the composite. After compression, the press was immediately cooled by running cold water before removing the composite from the press.

\subsubsection{PP-jute composites}

The PP and jute fibers were carded separately. After preparing the carded fibers, the required ratio of $\mathrm{PP} /$ jute fibers was weighed and carded together three times to obtain homogenous mixing of the fibers. Mats of the fiber blends were removed from the carding machine and cut to $25 \mathrm{~cm} \times 30.5 \mathrm{~cm}$ pieces. Several fiber mats were stacked to get the required weight/unit area and were later compression molded at $193{ }^{\circ} \mathrm{C}$ for $90 \mathrm{~s}$. The temperature and time required to make the PP-jute composites were optimized in our earlier researches (Huda and Yang, 2008a, 2008b, 2009a, 2009b).

\subsection{Composite characterization}

\subsubsection{Morphology}

The surface and cross-section of the composites was observed using a variable pressure scanning electron microscope (VPSEM) (Hitachi, S 3000N). Samples were sputter coated with gold-palladium before observing under the SEM.

\subsubsection{Flexural properties}

All samples were conditioned in a standard testing atmosphere of $21^{\circ} \mathrm{C}$ and $65 \%$ relative humidity for at least $24 \mathrm{~h}$ before testing. Flexural tests were done according to ASTM standard D790-03 on a MTS (Model Q Test 10; MTS Corporation, Eden Prairie, MN) tensile tester equipped with a $500 \mathrm{~N}$ load cell on samples with length of $20.3 \mathrm{~cm}$ and width of $7.6 \mathrm{~cm}$. The crosshead speed used was $10 \mathrm{~mm} / \mathrm{min}$. Six samples from three dif- 


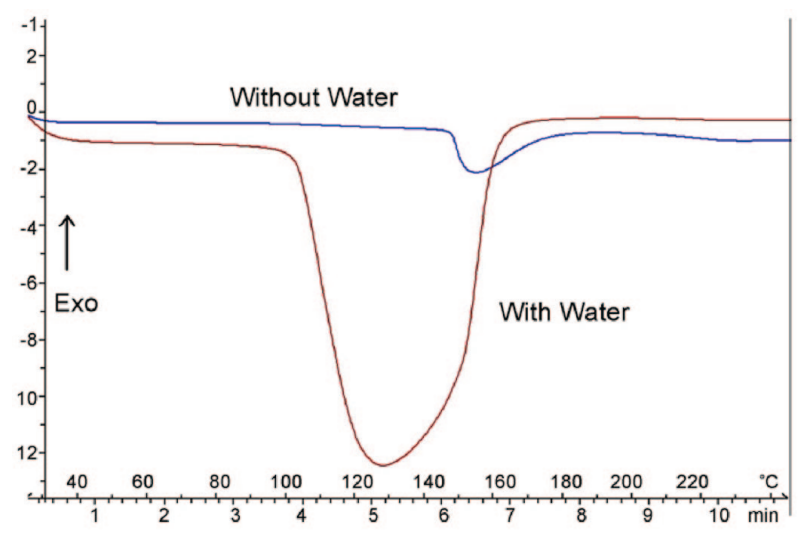

Figure 1. DSC thermogram of soyprotein with and without water as plasticizer. The thermograms were obtained at a heating rate of $20^{\circ} \mathrm{C} /$ $\min$.

ferent composites were tested for the flexural properties and the average and \pm one standard deviations are reported.

\subsubsection{Tensile properties}

Tensile tests were performed on an Instron tensile tester (Model 4000, Instron, Norwood, MA) according to ASTM standard D638-03 using dog-bone shaped specimens with length $165 \mathrm{~mm}, 19 \mathrm{~mm}$ width at the widest section and $13 \mathrm{~mm}$ width at the narrow section. Gauge length was $115 \mathrm{~mm}$ and crosshead speed was $5 \mathrm{~mm} / \mathrm{min}$. Six samples from three different composites were tested for the tensile properties and the average and \pm one standard deviations are reported.

\subsubsection{Acoustic properties}

The sound absorption properties of the composites were determined according to ASTM standard C423-99A on a small size Bruel \& Kjaer impedance tube. Three samples from different composites were tested for the sound absorption and the average readings were used to plot the absorption coefficient curves.

\subsection{Thermal behavior}

The thermal behavior of the soyproteins without and with water $(200 \%$ by weight of soyprotein) as plasticizer was studied using a Mettler Toledo Differential Scanning Calorimeter (Model: DSC822 $)$. The samples were placed in sealed aluminum pans and heated at $20^{\circ} \mathrm{C} / \mathrm{min}$ up to $250^{\circ} \mathrm{C}$.

\section{Results and discussion}

\subsection{Thermal behavior of soyprotein plasticized with water}

Figure 1 shows the DSC thermogram of the soyproteins with and without water as plasticizer. Soyproteins without water as plasticizer have a small melting peak between 150 and $170{ }^{\circ} \mathrm{C}$ which is most likely due to the removal of any residual moisture tightly bound to the proteins and degradation of impurities and melting of low molecular weight proteins. The melting peak could also be due to the proteins that have been denatured during the commercial preparation of soyproteins (Zhang et al., 2001). Water effectively plasticized soyprotein and decreased the melting temperature to about $130^{\circ} \mathrm{C}$. However, the optimum temperature for composite fabrication was between 150 and $180^{\circ} \mathrm{C}$. The higher temperatures for composite fabrication are necessary to ensure the complete removal of water used as plasticizer from the soyproteins and jute fibers. The melting peak of soyprotein with water as plasticizer had a melting enthalpy of $1.4 \mathrm{~kJ} / \mathrm{g}$ compared to $76 \mathrm{~J} / \mathrm{g}$ for the (a)

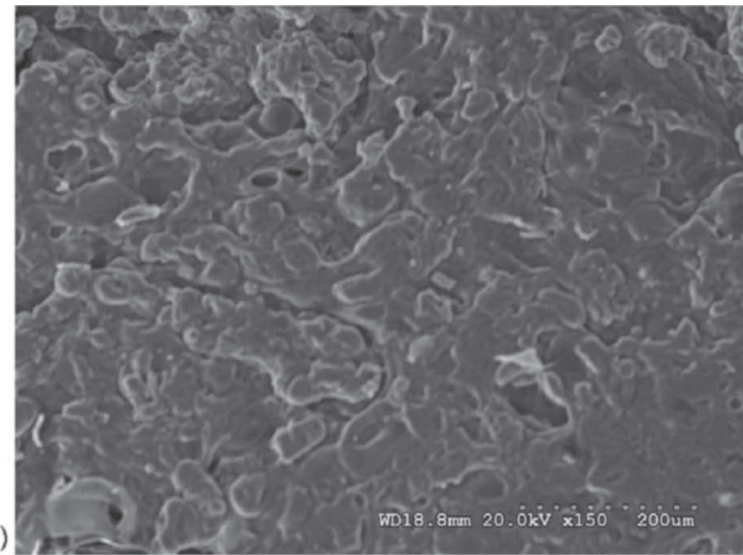

(b)

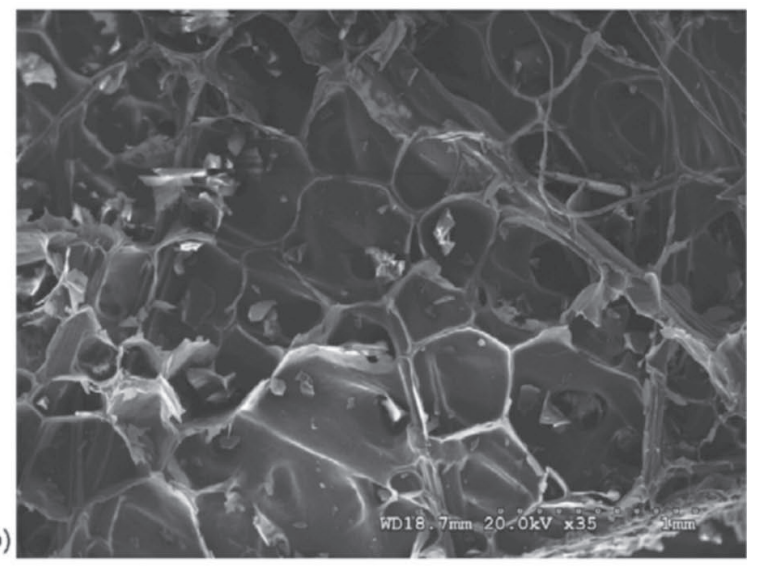

(c)

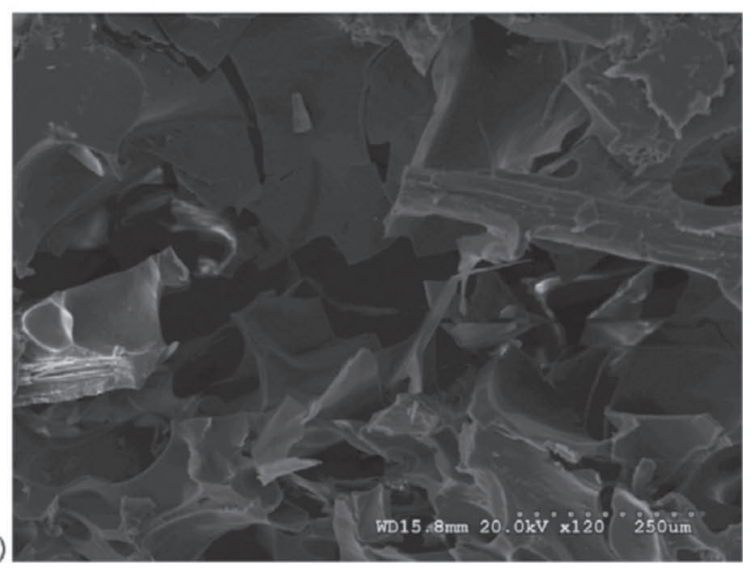

Figure 2. SEM image of the surface (a) and cross-sections (b and c) of the soyprotein composite containing $60 \%$ soyprotein and $40 \%$ jute and compression molded at $170^{\circ} \mathrm{C}$ for $15 \mathrm{~min}$. The formation of hexagonal shaped cells are seen in Figure $2 \mathrm{~b}$ and the jute fibers embedded in the soyprotein matrix are seen in (c).

non-plasticized soyproteins. The low melting temperature and high melting enthalpy of the soyproteins with water as the plasticizer allows the use of soyprotein as the matrix without damaging the soyproteins. It has also been reported that water was more effective as a plasticizer for wheat gluten compared to glycerol and sorbitol (Pouplin et al., 1999).

\subsection{Morphology of the composites}

Figure $2 \mathrm{a}$ shows the surface and Figs. $2 \mathrm{~b}$ and $\mathrm{c}$ show the crosssection of the soyprotein composites. As seen from Figure $2 \mathrm{a}$ soyprotein on the surface of the composites had melted and had 


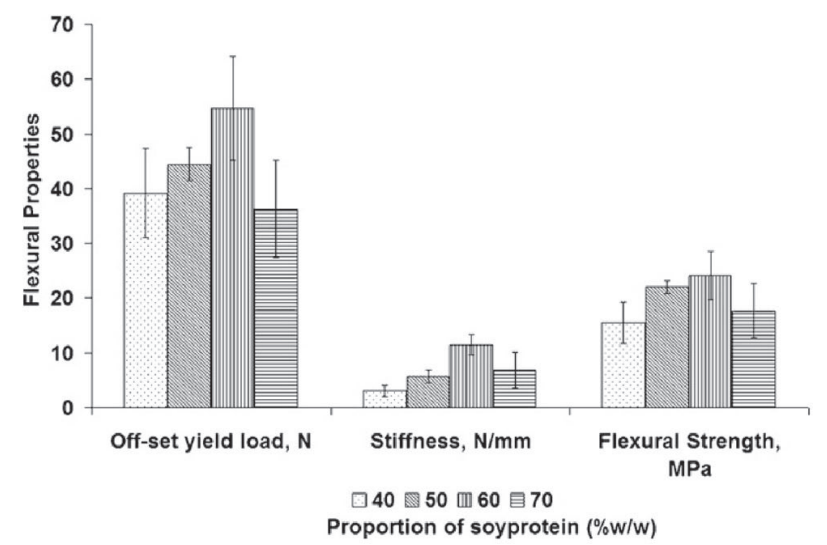

Figure 3. Effect of proportion $(\% \mathrm{w} / \mathrm{w})$ of soyprotein on the flexural properties of the composites. The composites with weight per unit area of $1500 \mathrm{~g} / \mathrm{m}^{2}$ (density $470 \mathrm{~kg} / \mathrm{m}^{3}$ ) were manufactured by compression molding at $170{ }^{\circ} \mathrm{C}$ for $15 \mathrm{~min}$.

a non-uniform surface. The cross-section of the composite in Figure $2 \mathrm{~b}$ reveals hexagonal shaped structures and Figure $2 \mathrm{c}$ shows the jute fiber embedded in the soyprotein matrix suggesting that soyprotein has been plasticized and will provide good binding to the jute fibers leading to composites with good properties.

\subsection{Effect of proportion of soyprotein on flexural properties}

The effect of increasing concentration of soyprotein in the composites on the flexural properties is shown in Figure 3. Low concentrations of soyprotein $(40 \%)$ do not provide enough matrix polymers to bind the jute fibers together and therefore the composites with $40 \%$ soyproteins have relatively poor flexural properties compared to other concentrations of soyproteins studied in this research. Composites containing 50\% soyproteins as matrix and $50 \%$ jute fibers as reinforcement have better flexural properties than composites with $40 \%$ soyproteins but lower than the composites containing $60 \%$ soyprotein. Composites having $60 \%$ soyproteins exhibit the highest flexural properties among all the proportions studied. At 60\% soyprotein, the composites had a off-set yield load of $55 \mathrm{~N}$, stiffness of $11.5 \mathrm{~N} / \mathrm{mm}$ and flexural strength of $24 \mathrm{MPa}$, higher than the offset yield load, stiffness and flexural strength of the composite with $50 \%$ soyproteins by 23,200 and $9 \%$, respectively. However, further increase in the concentration of soyprotein to $70 \%$ decreases the flexural properties. At $70 \%$ soyproteins, the composites do not have sufficient reinforcing material and therefore the flexural properties, especially the offset yield load, shows a sharp decrease of $34 \%$ compared to the offset yield load of the composite with $60 \%$ soyprotein.

\subsection{Effect of compression time on flexural properties}

Short compression times do not provide sufficient energy for the soyproteins to melt and reinforce the jute fibers resulting in poor flexural properties as seen from Figure 4. Increasing compression time from 10 to 15 min substantially increases the offset yield load, stiffness and flexural strength. The offset yield load and stiffness of the composites show a $200 \%$ increase when compression time is increased from 10 to $15 \mathrm{~min}$ but does not change from 15 to $20 \mathrm{~min}$. The flexural strength of the composites also shows considerable increase from 16.5 to $24 \mathrm{MPa}$ when the compression time is increased from 10 to $15 \mathrm{~min}$. At short compression times, the soyproteins may not melt sufficiently to provide good adhesion to the jute fibers resulting in inferior properties. Increasing compression time facilitates better binding between the soyprotein matrix and jute fibers and provides composites with good properties. However, excessive compression

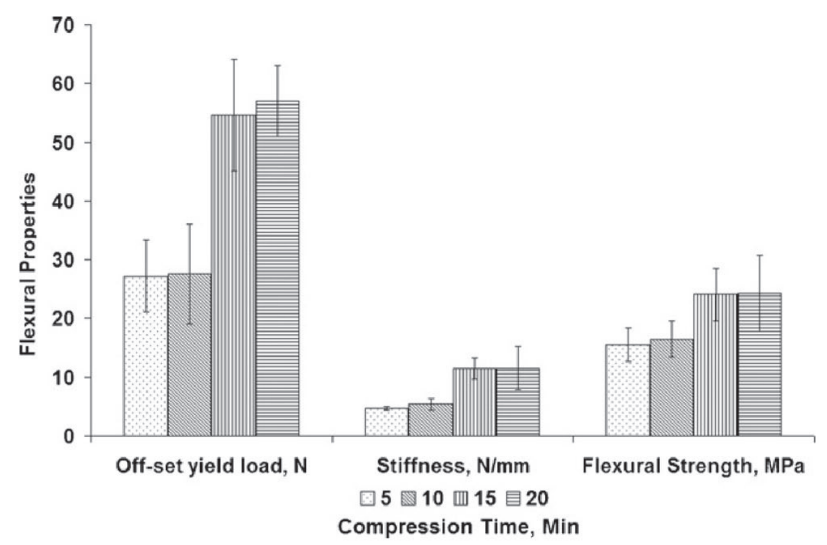

Figure 4. Effect of compression molding time on the flexural properties of the composites. The composites with a density $470 \mathrm{~kg} / \mathrm{m}^{3}$ were manufactured using $60 \%$ soyprotein and $40 \%$ jute fibers and compression molded at $170{ }^{\circ} \mathrm{C}$.

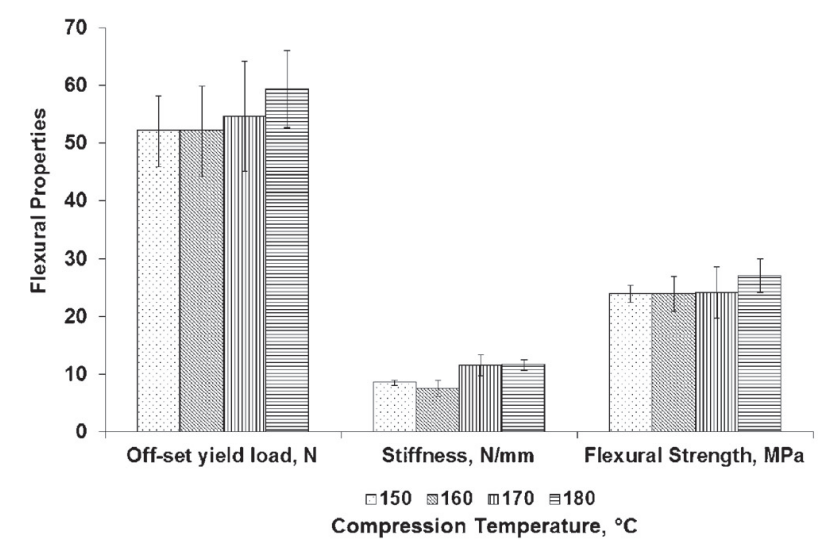

Figure 5. Effect of compression molding temperature on the flexural properties of the composites. The composites with a density of $470 \mathrm{~kg} / \mathrm{m}^{3}$ were manufactured using $60 \%$ soyprotein and $40 \%$ jute fibers and compression molded for $15 \mathrm{~min}$.

time will render the soyproteins to be brittle and could adversely affect the properties of the composites.

\subsection{Effect of compression temperature on the flexural properties}

Compression temperature does not show any considerable effect on the flexural properties of the composites as seen from Figure 5 . The offset yield load increases by $13 \%$ when the compression temperature is increased from 150 to $180{ }^{\circ} \mathrm{C}$. The stiffness of the composites shows an increase of $37 \%$ whereas the flexural strength increases by $13 \%$ with temperature increasing from 150 to $180{ }^{\circ} \mathrm{C}$. The compression temperature and time are related and the compression time of $15 \mathrm{~min}$ used to understand the effect of temperature is probably sufficient to melt the soyproteins and provide good flexural properties. The same extent of thermoplasticity of soyproteins could be obtained if higher temperatures but shorter times were used. Therefore, the flexural properties of the composites do not show a major change with increase in compression temperatures from 150 to $180^{\circ} \mathrm{C}$.

\subsection{Effect of composite fabrication conditions on tensile properties}

Table 1 shows the effect of composite fabrication conditions on the tensile properties of the composites. As seen from the table, increasing the proportion of soyproteins from 40 to $50 \%$ in- 
Table 1. Effect of proportion of soyproteins and composite fabrication time and temperature on the tensile properties of the composites. The composites were manufactured with a weight per unit area of $1500 \mathrm{~g} /$ $\mathrm{m}^{2}$ (density of $\left.470 \mathrm{~kg} / \mathrm{m}^{3}\right)$ and thickness of $3.2 \mathrm{~mm}$.

\begin{tabular}{|c|c|c|}
\hline & Strength, $\mathrm{MPa}$ & Modulus, GPa \\
\hline \multicolumn{3}{|c|}{ Soyprotein/jute $(\% \mathrm{w} / \mathrm{w})\left(170^{\circ} \mathrm{C}, 15 \mathrm{~min}\right)$} \\
\hline $40 / 60$ & $61.0 \pm 7.7$ & $5.4 \pm 0.3$ \\
\hline $50 / 50$ & $69.7 \pm 14.3$ & $5.9 \pm 0.8$ \\
\hline $60 / 40$ & $67.0 \pm 14.6$ & $6.4 \pm 0.6$ \\
\hline $70 / 30$ & $36.5 \pm 5.8$ & $4.2 \pm 1.4$ \\
\hline \multicolumn{3}{|c|}{ Compression temperature $\left({ }^{\circ} \mathrm{C}\right)(60 \%$ soyprotein, $15 \mathrm{~min})$} \\
\hline 150 & $64.0 \pm 7.5$ & $7.4 \pm 0.2$ \\
\hline 160 & $62.0 \pm 9.1$ & $6.6 \pm 0.6$ \\
\hline 170 & $67.0 \pm 14.6$ & $6.4 \pm 0.6$ \\
\hline 180 & $56.9 \pm 8.6$ & $6.7 \pm 0.4$ \\
\hline \multicolumn{3}{|c|}{ Compression time ( $\mathrm{min})(60 \%$ soyprotein, $15 \mathrm{~min})$} \\
\hline 5 & $60.0 \pm 9.1$ & $6.1 \pm 0.4$ \\
\hline 10 & $60.6 \pm 13.6$ & $5.9 \pm 0.6$ \\
\hline 15 & $67.0 \pm 14.6$ & $6.4 \pm 0.6$ \\
\hline 20 & $76.5 \pm 8.8$ & $6.7 \pm 1.0$ \\
\hline
\end{tabular}

creased the strength by about $15 \%$ and modulus by about $9 \%$. Further increasing the concentration of soyproteins from 50 to $60 \%$ slightly decreased the strength but increased the modulus by about $8 \%$. However, increasing in soyprotein concentration from 60 to $70 \%$ substantially decreased both the tensile strength and modulus. Composite fabrication temperature from 150 to $170{ }^{\circ} \mathrm{C}$ increased strength but the tensile strength decreased when temperature was increased from 170 to $180{ }^{\circ} \mathrm{C}$. However, the modulus of the composites did not decrease with increasing temperature and in fact composites fabricated at $150{ }^{\circ} \mathrm{C}$ had the highest tensile modulus. Tensile strength of the composites was similar at compression times of 5 and 10 min but increased with further increase in compression time to 15 and $20 \mathrm{~min}$. A compression time of 20 min provided the highest strength and modulus to the composites. Composites developed using acrylated epoxidized soybean oil and flax fiber mats as reinforcements had tensile strength ranging from 50 to $78 \mathrm{MPa}$ and tensile modulus ranging from 5 to 9.7 GPa depending on the amount of flax fibers (40-70\%), similar to the tensile properties of the composites developed in this research (Akesson et al., 2009). Various combinations of time (10$20 \mathrm{~min}$ ) and temperature $\left(160\right.$ to $\left.180^{\circ} \mathrm{C}\right)$ of composite fabrication can be selected to obtain similar composite properties.

\subsection{Sound absorption}

Figure 6 shows the sound absorption co-efficient of the soyprotein composites at various frequencies in comparison to similar composites developed using polypropylene as the matrix and jute fibers as reinforcement. As seen from the Figure, soyprotein composites $\left(60 \%\right.$ soyprotein/ $40 \%$ jute, $170{ }^{\circ} \mathrm{C}$, $15 \mathrm{~min}$ ) had much higher sound absorption than the PP-jute composites in the frequency range of $1.0-4.0 \mathrm{kHz}$. The absorption of the soyprotein composites decreased above a frequency of $4.0 \mathrm{kHz}$ while that of the PP-jute composites increased continuously. The higher sound absorption of the soyprotein composites than PP-jute composites is probably due to the creation of voids between the soyprotein and jute fibers as seen from the SEM images in Figure 2.

\subsection{Comparison of the properties of the soyprotein and poly- propylene composites}

Table 2 provides a comparison of the properties of the soyprotein composites ( $60 \%$ soyprotein, $170^{\circ} \mathrm{C}, 15 \mathrm{~min}$ ) with polypropylene composites $\left(40 \% \mathrm{PP}, 190^{\circ} \mathrm{C}, 90 \mathrm{~s}\right)$ at two different humidities. As seen from the table, the soyprotein composites had much better flexural and tensile properties than the

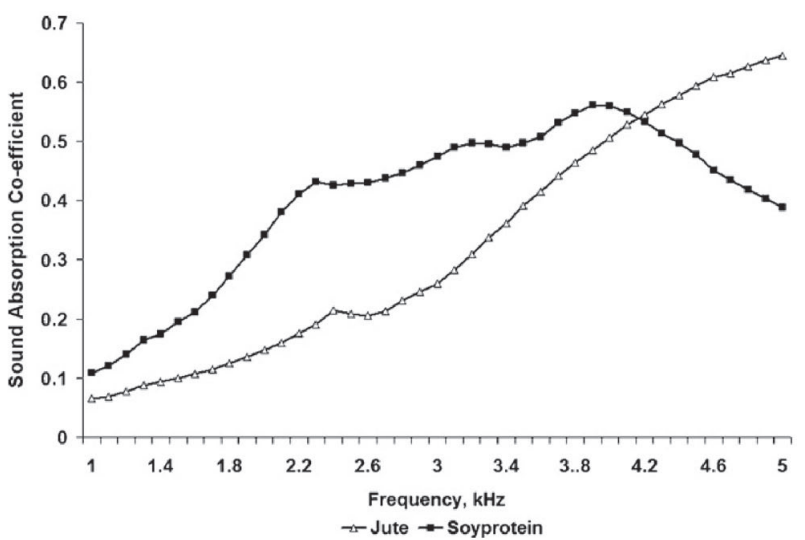

Figure 6. Sound absorption coefficients of the soyprotein-jute composites compared to PP-jute composites. The composites with a density $470 \mathrm{~kg} / \mathrm{m}^{3}$ were manufactured using $60 \%$ soyprotein and $40 \%$ jute fibers and compression molded at $170{ }^{\circ} \mathrm{C}$ for $15 \mathrm{~min}$.

PP composites at $21{ }^{\circ} \mathrm{C}$ and $65 \%$ relative humidity. The soyprotein composites had about $127 \%$ higher flexural strength, 8 $0 \%$ higher tensile strength and about $90 \%$ higher tensile modulus than the polypropylene composites at $21^{\circ} \mathrm{C}$ and $65 \%$ relative humidity. However, the nearly 8 times higher stiffness and modulus of elasticity of the soyprotein composites than the PP composites shows that the soyprotein composites are much more brittle than the PP composites. PP is more flexible and allows the jute fibers to bend more easily than the rigid soyproteins. Therefore, the PP composites have lower stiffness and modulus of elasticity (MOE) than the soyprotein composites. The better properties of the soyprotein-jute composites compared to the PP-jute composites should mainly be due to the better interaction between soyprotein and jute fibers. Both soyprotein and jute fibers are hydrophilic and would therefore have good compatibility compared to the hydrophobic PP and hydrophilic jute fibers.

The flexural and tensile properties of the soyprotein composites decreased considerable at $90 \%$ relative humidity compared to the respective properties at $65 \%$ relative humidity. There was a $53 \%$ decrease in flexural strength, $86 \%$ decrease in stiffness and MOE, 24\% decrease in tensile strength and 31\% decrease in the tensile modulus of the soyprotein composites at $90 \%$ relative humidity. The PP composites did not show any considerable decrease in the flexural properties but the tensile strength decreased by about $11 \%$ and the tensile modulus decreased by about $25 \%$ at $90 \%$ relative humidity. The large decrease in the properties of the soyprotein composites should be due to the absorption of moisture and softening of the soyproteins. Softened soyproteins will decrease the interfacial binding strength between the soyproteins and jute fibers and also allow the jute fibers to be more flexible. Poor interfacial strength leads to a decrease in the flexural and tensile strength and the higher flexibility of the jute fibers will decrease the stiffness and MOE of the composites. Similar decrease in the flexural and tensile properties of soy-based composites with increasing plasticizer (glycerol) content was previously observed (Chabba and Netravali, 2005a, 2005b).

Although the soyprotein composites have inferior properties at high humidities compared to their properties at low humidity, both the tensile and flexural properties of the soyprotein composites at $90 \%$ relative humidity are better than that of the PP composites at $90 \%$ relative humidity. As seen from Table 2 , the soyprotein composites have about $7 \%$ higher flexural strength, $57 \%$ higher tensile strength and $75 \%$ higher tensile modulus than the PP composites at $21^{\circ} \mathrm{C}$ and $90 \%$ relative humidity. The stiffness and MOE of the soyprotein composites 
Table 2. Comparison of the optimized flexural and tensile properties of the soyprotein-jute composites with polypropylene-jute composites at two different humidities.

\begin{tabular}{clllll}
\hline Matrix material & $\begin{array}{l}\text { Flexural } \\
\text { strength, } \mathrm{MPa}\end{array}$ & $\begin{array}{l}\text { Stiffness, } \\
\mathrm{N} / \mathrm{mm}\end{array}$ & $\begin{array}{l}\text { Modulus of } \\
\text { elasticity, } \mathrm{MPa}\end{array}$ & $\begin{array}{l}\text { Tensile } \\
\text { strength, MPa }\end{array}$ & $\begin{array}{l}\text { Tensile } \\
\text { modulus, GPa }\end{array}$ \\
\hline $21^{\circ} \mathrm{C}, 65 \% \mathrm{RH}$ & & & & & \\
$\quad \begin{array}{l}\text { Soyprotein } \\
\text { Polypropylene }\end{array}$ & $24.1 \pm 4.4$ & $11.5 \pm 1.8$ & $4074 \pm 648$ & $64.0 \pm 5.7$ & $6.1 \pm 0.8$ \\
$21^{\circ} \mathrm{C}, 90 \% \mathrm{RH}$ & $10.6 \pm 1.1$ & $1.4 \pm 0.2$ & $500 \pm 79$ & $35.2 \pm 5.5$ & $3.2 \pm 0.6$ \\
$\quad \begin{array}{l}\text { Soyprotein } \\
\text { Polypropylene }\end{array}$ & $11.3 \pm 2.5$ & $1.6 \pm 0.4$ & $558 \pm 144$ & $49.0 \pm 7.5$ & $4.2 \pm 0.4$ \\
\hline
\end{tabular}

Table 3. Comparison of the flexural and tensile properties of soyprotein-jute composites developed in this research with some unmodified soyprotein-natural fiber composites.

\begin{tabular}{|c|c|c|c|c|c|c|c|}
\hline \multirow{2}{*}{$\begin{array}{l}\text { Reinforcing } \\
\text { fiber }\end{array}$} & \multicolumn{2}{|c|}{ Flexural properties } & \multicolumn{2}{|c|}{ Tensile properties } & \multicolumn{2}{|l|}{ Plasticizer } & \multirow[t]{2}{*}{ Reference } \\
\hline & Strength, $\mathrm{MPa}$ & Modulus GPa & Strength $\mathrm{MPa}$ & Modulus GPa & Type & $\%$ & \\
\hline Hemp (25\%) & - & - & 15.45 & 0.60 & Thiodiglycol & 30 & Wang et al. (2009) \\
\hline Banana $(30 \%)$ & - & - & $1.62 \pm 0.15$ & $0.25 \pm 0.08$ & Glycerol & 50 & Kumar et al. (2008) \\
\hline Jute $(40 \%)$ & $24.1 \pm 4.1$ & $4.1 \pm 0.6$ & $64.0 \pm 5.7$ & $6.1 \pm 0.8$ & Water & 100 & This paper \\
\hline
\end{tabular}

are also higher by 14 and $13 \%$, respectively compared to the PP composites. Better properties of the soyprotein composites than the PP composites even at high humidities suggests that the soyprotein composites have potential to be used in applications currently using PP-based composites.

\subsection{Comparison with literature on unmodified soyprotein- natural fiber composites}

Table 3 provides a comparison of tensile and flexural properties of some of the soyprotein-natural fiber composites previously reported. However, it should be noted that the composite fabrication conditions such as the density and thickness and testing conditions such as relative humidity and temperature are different among the composites compared in Table 3 and could have considerable influence on the properties of the composites. As seen from the table, the soyprotein composites developed using water as plasticizer have much higher tensile strength and modulus than the soyprotein composites developed using hemp and banana fibers as reinforcement and thiodiglycol and glycerol as plasticizer $(\mathrm{Ku}-$ mar et al., 2008; Wang et al., 2009). The inferior properties of the hemp and banana fiber reinforced soyprotein composites should mainly be due to the presence of plasticizers (Lodha and Netravali, 2005). It has been shown that increasing glycerol content considerably decreases the strength but increases the elongation of soyprotein films and composites (Lodha and Netravali, 2005). Soyprotein composites reinforced with ramie fibers have much higher flexural and tensile strength but lower tensile modulus most likely due to the lower thickness $(0.7-0.8 \mathrm{~mm})$ and higher density compared to the composites developed in this research. Other literature available on soyprotein composites have chemically modified the soyprotein and/or have used other matrix materials to develop composites and are therefore not appropriate for comparison with the composites developed in this research.

\section{Conclusions}

This research shows water without any chemicals can effectively plasticize and make soyprotein thermoplastic. The thermoplastic soyprotein can act as a binder and provide composites with much better flexural and tensile properties than similar composites developed using PP as the matrix polymer. Water decreases the melting temperature and also provides a much higher melting enthalpy to soyproteins. Composites developed using $60 \%$ soyproteins and $40 \%$ jute fibers and compression molded at $170{ }^{\circ} \mathrm{C}$ and $15 \mathrm{~min}$ had optimum properties. At the optimized conditions, the soyprotein composites have more than twice the flexural strength and more than 80 and $90 \%$ higher tensile strength and tensile modulus, respectively, than PP composites. Although the flexural and tensile properties of the soyprotein composites decrease substantially at $90 \%$ relative humidity, the soyprotein composites show better properties than the PP composites even at high humidities. Soyprotein composites also had better sound absorption than the PP composites. Utilizing water as a plasticizer will not only decrease the cost but also make the process completely green since no chemicals are used. The soyprotein composites developed in this research are biodegradable and show potential for use in various applications.

Acknowledgments - The authors wish to thank the Agricultural Research Division at the University of Nebraska-Lincoln, USDA Hatch Act, and Multistate Research Project S1026 for their financial support to complete this work.

\section{References}

Akesson et al., 2009 • D. Akesson, M. Skrifvars, and P. Walkenstrom, Preparation of thermoset composites from natural fibres and acrylate modified soybean oil resins, J. Appl. Polym. Sci. 114 (2009), pp. 2502-2508.

Barkoula et al., 2010 - N. M. Barkoula, S. K. Garkhail, and T. Peijs, Biodegradable composites based on flax/polyhydroxybutryate and its copolymer with hydroxyvalerate, Ind. Crops Prod. 31 (2010), pp. 34-42.

Chabba and Netravali, 2005a - S. Chabba and A. N. Netravali, Green composites. Part 1: characterization of flax yarn and glutaraldehyde modified soyprotein concentrate composites, J. Mater. Sci. 40 (2005), pp. 6263-6273.

Chabba and Netravali, 2005b - S. Chabba and A. N. Netravali, Green composites. Part 2: characterization of flax yarn and glutaraldehyde/poly(vinyl alcohol) modified soyprotein concentrate composites, J. Mater. Sci. 40 (2005), pp. 6275-6282.

Chabba et al., 2005 - S. Chabba, G. F. Matthews, and A. N. Netravali, Green composites using cross-linked soy flour and flax yarns, Green Chem. 7 (2005), pp. 576-581. 
Cheesborough et al., 2008 • V. Cheesborough, K. Rosentrater, and J. Visser, Properties of distillers grains composites: a preliminary investigation, J. Polym. Environ. 16 (2008), pp. 40-50.

El-Wakil et al., 2007 • N. A. El-Wakil, R. E. Abou-Zeid, Y. Fahmy, and A. Y. Mohamed, Modified wheat gluten as a binder in particle board made from reed, J. Appl. Polym. Sci. 106 (2007), pp. 3592-3599.

Huda and Yang, 2008a - S. Huda and Y. Yang, Composites from ground chicken quill and polypropylene, Comp. Sci. Technol. 68 (34) (2008), pp. 790-798.

Huda and Yang, 2008b • S. Huda and Y. Yang, Chemically extracted cornhusk fibers as reinforcement in light-weight polypropylene composites, Macromol. Mater. Eng. 293 (3) (2008), pp. 235-243.

Huda and Yang, 2009a - S. Huda and Y. Yang, Feather fiber reinforced light-weight composites with good acoustic properties, J. Polym. Environ. 17 (2) (2009), pp. 131.10-142.10.

Huda and Yang, 2009b - S. Huda and Y. Yang, A novel approach of manufacturing light-weight composites with polypropylene web and mechanically split cornhusk, Ind. Crops Prod. 30 (1) (2009), pp. $17-23$.

Kim, 2008 - S. Kim, Processing and properties of gluten/zein composite, Bioresour. Technol. 99 (2008), pp. 2032-2036.

Kumar et al., 2002 • R. Kumar, V. Choudhary, S. Mishra, I. K. Varma, and B. Mattiason, Adhesives and plastics based on soy protein products, Ind. Crops Prod. 16 (2002), pp. 155-172.

Kumar et al., 2008 - R. Kumar, V. Choudhary, S. Mishra, and I. K. Varma, Banana fiber-reinforced biodegradable soy protein composites, Front. Chem. China 3 (3) (2008), pp. 243-250.

Kunanopparat et al., 2008 • T. Kunanopparat, P. Menut, M. H. Morel, and S. Guilbert, Reinforcement of plasticized wheat gluten with natural fibers: from mechanical improvement to deplasticizing effect, Compos. A 39 (5) (2008), pp. 777-785.

Liu et al., 2006 - Z. Liu, S. Z. Erhan, D. E. Akin, and F. E. Barton, Green composites from renewable resources: preparation of epoxidized soybean oil and flax fiber composites, J. Agric. Food Chem. 54 (2006), pp. 2134-2137.

Liu et al., 2008 - Z. Liu, S. Z. Erhan, D. E. Akin, F. E. Barton, C. Onwulata, and T. A. Mckeon, Modified flax fibers reinforced soy-based composites: mechanical properties and water absorption behavior, Compos. Interfaces 15 (2-3) (2008), pp. 207-220.

Lodha and Netravali, $2005 \cdot$ P. Lodha and A. N. Netravali, Characterization of stearic acid modified soy protein isolate resin and ramie fiber reinforced green composites, Comp. Sci. Technol. 65 (2005), pp. 1211-1225.

Mohanty et al., 2000 - A. K. Mohanty, M. Misra, and G. Hinrichsen, Biofibers, biodegradable polymers and biocomposites: an overview, Macromol. Mater. Eng. 276/277 (2000), pp. 1-24.
Otaigbe et al., 1999 - J. U. Otaigbe, H. Goel, T. Babcock, and J. Jane, Processability and properties of biodegradable plastics made from agricultural biopolymers, J. Elastomers Plastics 31 (1999), pp. 56-71.

Pouplin et al., 1999 • M. Pouplin, A. Redl, and N. Gontard, Glass transition of wheat gluten plasticized with water, glycerol, or sorbitol, J. Agric. Food Chem. 47 (1999), pp. 538-543.

Quirino and Larock, 2009 - R. L. Quirino and R. C. Larock, Synthesis and properties of soy hull-reinforced biocomposites from conjugated soybean oil, J. Appl. Polym. Sci. 112 (2009), pp. 2033-2043.

Reddy and Yang, 2005 - N. Reddy and Y. Yang, Properties and potential applications of natural cellulose fibers obtained from cornhusks, Green Chem. 7 (4) (2005), pp. 190-195.

Reddy and Yang, 2009a - N. Reddy and Y. Yang, Natural cellulose fibers from soybean straw, Bioresour. Technol. 100 (2009), pp. 3593-3598.

Reddy and Yang, 2009b • N. Reddy and Y. Yang, Properties and the potential applications of natural cellulose fibers from the bark of cotton stalks, Bioresour. Technol. 100 (2009), pp. 3563-3569.

Song et al., 2008 - Y. Song, Q. Zheng, and C. Liu, Green composites from wheat gluten and hydroxyethyl cellulose: processing and properties, Ind. Crops Prod. 28 (2008), pp. 56-62.

Song and Zheng, $2009 \cdot$ Y. Song and Q. Zheng, Structure and properties of methycellulose microfiber reinforced wheat gluten based green composites, Ind. Crops Prod. 29 (2009), pp. 446-454.

Tatara et al., 2009 - R. A. Tatara, K. A. Rosentrater, and S. Suraparaju, Design properties for molded, corn-based DDGS-filled phenolic resin, Ind. Crops Prod. 29 (2009), pp. 9-15.

Tran et al., 2006 - P. Tran, D. Graiver, and R. Narayan, Biocomposites synthesized from chemically modified soy oil and biofibers, J. Appl. Polym. Sci. 102 (2006), pp. 69-75.

Wang et al., 2009 • L. Wang, R. Kumar, and L. Zhang, Investigation into hemp fiber-and whisker-reinforced soy protein composites, Front. Chem. China 4 (3) (2009), pp. 313-320.

Wretfors et al., 2009 • C. Wretfors, S. Cho, M. S. Hedenqvist, S. Marttila, S. Nimmermark, and E. Johansson, Use of industrial hemp fibers as reinforcement for wheat gluten plastics, J. Polym. Environ. 17 (2009), pp. 259-266.

Zhang et al., 2001 - J. Zhang, P. Mungara, and J. Jane, Mechanical and thermal properties of extruded soyprotein sheets, Polymer $\mathbf{4 2}$ (2001), pp. 2569-2578.

Zou et al., $2010 \bullet$ Y. Zou, S. Huda, and Y. Yang, Light-weight composites from long wheat straw and polypropylene web, Bioresour. Technol. 101 (6) (2010), pp. 2026-2033. 